\title{
RETRACTED: MODEL PEMBELAJARAN LANGSUNG BERBASIS MEDIA PASIR BERWARNA TERHADAP KEMAMPUAN PEMAHAMAN KONSEP ANGKA 1-10
}

\author{
Putrie Mei Atika \\ Pendidikan Luar Biasa, Fakultas Ilmu Pendidikan, Universitas Negeri Surabaya \\ putriemeiatika@yahoo.co.id \\ Sri Joeda Andajani \\ Pendidikan Luar Biasa, Fakultas Ilmu Pendidikan, Universitas Negeri Surabaya \\ sri.joeda@gmail.com
}

\begin{abstract}
Abstrak
Menyusul penilaian yang ketat dan hati-hati, telah dipertimbangkan penarikan dari artikel yang diterbitkan dalam JPI (Jurnal Pendidikan Inklusi) yang berjudul "Model Pembelajaran Langsung Berbasis Media Pasir Berwarna Terhadap Kemampuan Pemahaman Konsep Angka 1-10" Volume 1, Nomor 2, hlm. 129-145, Oktober 2018, DOI: 10.26740/inklusi.v1n2.p105-116. Artikel ini telah ditemukan melanggar peraturan JPI (Jurnal Pendidikan Inklusi) dan telah ditarik kembali, artikel tersebut ditemukan melakukan publikasi ganda, Tim Redaksi menyelidiki dan menemukan bahwa makalah sudah diterbitkan dalam Jurnal Mahasiswa Universitas Negeri Surabaya: Jurnal Pendidikan Khusus Volume 9, dokumen dan isinya telah dihapus dari JPI (Jurnal Pendidikan Inklusi), dan harus dilakukan upaya untuk menghapus semua referensi ke artikel ini.
\end{abstract}

Keywords: Direct learning, number concept, autism children. 